\title{
Articles
}

\section{Values as a Pedagogical Research Topic}

\section{Adéla Antlová, Štefan Chudý}

\begin{abstract}
The aim of this paper is to contribute to the understanding of the term value as a common research topic and consequently point out how it should be reflected in a research design. There is an outline of such a design in the third part of the paper. The authors do not follow the common understanding of values as central beliefs. Instead, following Brožík's ideas, they consider them the outcome of the evaluation of relationships to different concrete or abstract objects around us. The content of this paper focuses on the values of a person, rather than a general understanding of the term. It offers the notion of values as the result of our everyday experience and therefore, it does not discuss the a priori existence of values. It rather focusses on how one's values (less and more central) are formed.
\end{abstract}

Key words: value, attitude, evaluation, research.

\section{Hodnoty jako téma pedagogického výzkumu}

\begin{abstract}
Abstrakt
Cílem tohoto příspěvku je přispět k porozumění pojmu hodnota jako frekventovanému výzkumnému tématu, a zároveň ukázat, jak toto pojetí uplatnit ve výzkumném designu. Návrh takového designu nalezne čtenář ve třetí části textu. Autoři se neopírají o časté chápání pojmu hodnota jako centrálního přesvědčení. Spíše vycházejí z Brožíkova
\end{abstract}


pojetí hodnoty jako výsledku hodnocení vztahu k různým konkrétním či abstraktním objektům kolem nás. Obsah článku se zaměřuje na hodnotový systém jedince spíše než na obecné charakteristiky termínu hodnota. Hodnoty jsou tu vnímány jako výsledek naší každodenní zkušenosti, proto se autoři nevyjadřují k existenci hodnot apriori, ale zaměřují se na proces utváření více či méně centrálních hodnot jedince.

Klíčová slova: hodnota, přístup, hodnocení, výzkum.

\section{Introduction}

Although values have been studied for so long there is no certainty about their definition or where they come from. The problem is they cover a too wide area of human existence. However, what makes it most difficult to come to some generalized understanding is the subjective nature of this hypothetic construct (Cakirpaloglu, 2009, 277). However, according to Brožík (2004, 47-52), it is necessary to separate subjectivism from relativism; because in the process of knowledge acquisition the relationships between different variables are most important, and it is relativity not subjectivity what depicts values most. Nevertheless, relativity makes values a demanding topic to study. Yet, there is some space, within their nature, which can be studied.

In our opinion, it is those researchers who operate with the values as if they were independent entities, who cause the gap to broaden between a person and values. People inaccurately tend to consider values the world around them instead of realizing they are the ones who create values themselves. It is them and the context which shape their life that affects the values of our society. This understanding is essential when we need to study, develop, affect, etc. values of an individual or the society.

Values are a common research topic because they are related to every field of science. We cannot find any area of human activity which is not influenced by values because values are the result of evaluation and evaluation is the basic human activity. It is present even in simple organisms, though in a very primitive mode, as a response to present experience and obviously without a cognitive component.

Values are the cause and the aim of human activity. Researchers are always interested in a few values of an individual, a group of people, a nation etc. but, in fact, they represent the overall image of the world and its meaning for the person. The value system of a person is permanently shaped by our daily experience and therefore, every research in values is always relative. 


\section{The Origin of Human Values}

It is problematic to understand what the essence of values is because they incorporate two principles. They are specific and general at the same time. Whether they were specific first and general afterwards or vice versa is a question which cannot be answered, and together with the question regarding the existence of God they will most probably stay unanswered. On the other hand, there are still a lot of problems concerning values, which can and must be investigated.

At first, we should be able to answer the question: What are values of an individual? and Where do one's values come from? Are values only the most influential beliefs as Rokeach (1973) says or do they form a complex system, which covers also negative values?

Rokeach regarded values essential beliefs because he felt there is a need to separate them from attitudes. In fact, these terms are often defined as if they were identical and the only difference is in the amount of importance of values apart from attitudes. For example, the Czech pedagogic dictionary describes value as "a subjective appraisal or the amount of importance which an individual attributes to certain objects, phenomena, symbols, other people etc." (Průcha, Walterová, Mareš, 2009, 91-92, translated by the author of the paper). Attitudes are described as "an evaluative relationship of a person to the world, other objects and to himself or herself" (Průcha, Walterová, Mareš, 2009, 210, translated by the author of the paper). It is not clear what the difference between these two terms is because the words like "subjective appraisal" or "amount of importance" belong to the category of evaluation. On the other hand, these definitions indicate that importance might play some role in this distinction.

On the contrary, we consider it unnecessary or even wrong to distinguish these terms in this aspect. At first, we consider both the terms to refer to the same relationship. What differs is that they refer to different aspects of the relationship. Both attitudes and values consist of three components, i.e. cognitive, affective and behavioural. They refer to our feelings, thoughts and behaviour in connection with certain objects. We claim that the only difference is that we use the word attitude when we need to describe what our feelings, thoughts and behaviour affected by a certain object are like. We use the word value to label the object. But they both originate in the same experience and refer to the same object (the word object is not accurate here, which will be specified later). In other words, it is not the result of our evaluation of an object what differentiates between attitudes and values.

Let us take a closer look at the definitions of the experts who devoted their lives to the study of values to broaden our understanding of terms value and attitude to be able to grasp what the difference between them is. Milton Rokeach (1970) describes values and attitudes as a system of beliefs, which can only be studied when they manifest in behaviour. Values are in the centre of the system of beliefs and therefore, there 
are fewer values than attitudes. Besides, value only refers to abstract ideals and ideal modes of behaviour.

"An attitude is a relatively enduring organization of beliefs around an object or situation predisposing one to respond in some preferential manner" (Rokeach, 1970, 112).

Value is "a type of belief, centrally located within one's total belief system, about how we ought or ought not to behave, or about some end-state of existence worth or not worth attaining" (Rokeach, 1970, 124).

Rokeach therefore stands against those who say that we have as many values as there are objects towards which we express certain relationship. Rokeach considers values only abstract ideals but we can easily find those for whom concrete objects are valuable and shape their activities. Moreover, when we think of certain value we always connect it with our experience. In other words, this generalized value always includes a concrete object (which can also be abstract) and is connected to our experience in our mind.

Next, if values are only central beliefs, where is the border between central and not central beliefs? How do we distinguish between values and attitudes if the border is not clear? We claim that the difference is not in the amount of importance. It is always values, not depending on the amount of importance we draw to it. Some values are more central than others, however, to be more precise, values form a complex system, and within this system, we can group some values and call them more central. Nevertheless, they are merely the generalization of more specific, more concrete values. These generalized values come from the synthesis of similar values, i.e. values which an individual integrates under one superordinate value, while the subordinate values are more often connected with positive experience than the values of less central position. But the structure is so blended and the experience so rich that we can never say that some value is only positive or negative. Nevertheless, more or less central, important etc. they are always called values.

We agree with Rokeach's notion of values as beliefs, which is shared by Cakirpaloglu $(2009,277)$ and Schwartz $(2015,3)$.

According to Schwartz, values are the central constituent of one's self-conception $(2015,2)$. Also Cakirpaloglu emphasizes the importance of values as the personality component. We come to an agreement here but we emphasize that only those values which are central to us are an important constituent of our personality.

We also agree that values lie more "in the eye of the beholder, not in the object of perception" (Schwartz, 2015, 3), and we agree that they affect how we evaluate the world around us. We only need to add that it is every single piece of experience what affects how we evaluate the world. Although there might be some inborn preferences (Vicario, 2013), which we consider necessary to prove; still they are shaped during our life.

We follow the notion of values described by Vladimír Brožík (2004). According to Brožík (2004, 82-84), values are mainly the product of human activity (besides natural 
forces) in which a person builds relationships with reality, i.e. conditions or outcomes of this activity, means, objects and circumstances which accompany this activity. Brožík refers to Vaross' definition of values as "quality of function, measured by adequate norm... which must be seen and accepted in relative structures in which it really exists in human praxis" (translated by the author of the text). This function (which is the object of evaluation), Brožík explains, is the relationship between two or more variables, and evaluation means to measure the quality of a certain function. Only secondary, the evaluation refers to the variables. To sum up, a value is not a characteristic feature of an object but the meaning of a certain characteristic feature of the object, which we created, and which exists in certain context. If something is valuable for us, it means it has certain meaning for us. It does not mean it is valuable for everybody.

What is the impact of Brožík's idea? Let us think about the value family. Following what has been stated, it is the synthesis of all the relationships to all people one considers family members, which were formed in different contexts. Besides, it includes the outcome of his or her experience with all families (even fictional) one encounters during his or her life. Every single constituent affects how we evaluate the whole. It is not easy therefore to say what the term family means for us because it covers all the feelings, acts and thoughts we have experienced. Besides, we consider it a gross simplification to ask someone to name his or her values, as it is meaningless. The value family of one person can be utterly different from someone else's meaining of the word. On the other hand, one's values are a rich source of one's experience.

When we follow this schema of the term value, we can easily understand why Cakirpaloglu $(2009,277)$ talks about a negative aspect of values. For us, values cover a whole range of feelings expressing the relationships to the objects from the most negative to the most positive ones.

Following the above mentioned, our definition of values is: value is the outcome of evaluation of our relationship to different objects around us (also abstract objects), which is permanently shaped by mutual interaction in a certain context. Every object is more or less valuable for us depending on the amount of positive experience with this object concerning our feelings, thoughts and acts.

\section{Research in Values}

The first question we need to ask when we plan to do a value survey is: What is the purpose of our research? Why do we study values of an individual? The answer to our question is the main indicator of our research design. In our case, the aim of our research is to identify the most central values of an individual. We aim to get to know the value system of an individual as thoroughly as possible. Therefore, the way how to reach it will differ from the approach of a quantitative researcher but they might get some 
inspiration how to enrich their research design or research tool, in order to minimize the simplification of the problem as well.

In the qualitative research, the researcher needs to find out who is the examined person, how he or she feels, thinks and behaves. In order to get a sufficient picture of a person, the study must be easily feasible and yet complex. Our research tool is based on the above outlined nature of values which form a complex system. The examined person reveals his or her values through their three components and thereby shows confirmative or contradictory relationships among them. Even if we endeavor to get the understanding of one's values, it is sure we will not reach it. We merely approach it, never get it utterly.

We suggest that the design consists of three parts, each part reflecting one component of values. At first, it is the behavioral component. Due to this component, even the most abstract value has a special, unique meaning for every person. A behavioral component emerges from one's experience. We are affected by a certain value (also more values), and under its influence, we make decisions, which lead to certain responses. We will call this component practical.

We can illustrate it with the value which is most important for most of us. This value is health. When two people think about health they do not mean the same thing. Both of them definitely refer to a good state of their body and mind and the absence of illness. Nevertheless, the way how they reach it will differ. Therefore, they will connect the value health with different activities. For one, health means to take antibiotics, for another to cure alternatively. Someone cures himself or herself by doing yoga, another by having a good night's sleep. For one person health means to be able to walk, for another, it means to be able to get up from bed. We can see that the same value is connected with utterly different behavioral responses.

In research, we can comprise this part like this: Participants are asked to close their eyes and concentrate on themselves, to think about themselves as a unique being. Next, they should imagine typical activities, which make them happy, and which they practice as much as possible. Participants write at least ten activities.

Another component is affective. As we get to know the world around us, we feel it at the same time. We examine its positive or negative effect on us. The affective memory, the affective mental maps are more natural, are prior to cognitive mental maps as they are the component of our personality we bring from the times we were more animals than human.

In research: Participants describe ten or more happy moments from their life. These are the moments which they connect with most positive feelings and which they treasure a lot. These could be also events which gave them strength, consolation, hope or help.

The last component is cognitive. These components together form a complex system, although there might not be an agreement between them. Sometimes what we 
do does not correspond with what we think and feel. On the other hand, if there is concordance between all the three components, the position of the value within the system of values will be more solid.

In research: Participants are asked to write what they consider the most important ideas, principles, rules according to which they live.

Before these three steps, participants are asked to write from ten to fifteen most important values. Participants are asked not to think about this task very much. Instead, they should use their instincts, imagination and emotions more than reason. A researcher looks for similarities, differences and extra information coming from different parts, and thus tries to create a list of important values. If a researcher needs to get even more accurate picture of value preferences of an individual, he or she can make it more contextualized by asking them to give a specific detail to every event, idea etc. The fact that the values are investigated through different components and compared with the former list of favorite values contributes to the "triangulation" (Hendl, 2005) of this research tool. The reappearance of certain value highlights its meaning for the participant. Participants are given a certain freedom in the number of required answers, which prevents they would have to leave out some values they consider important.

\section{Conclusion}

Values will be in the center of the concern of future generations as they are now since they represent a key part of human identity. We consider it necessary to make them think about the purpose of their study and thus use a qualitative approach to values where needed. We agree that there are areas of value research, in which we would hardly adopt the qualitative design we have outlined here. Nevertheless, the general idea about the origin and nature of values we described here should be the main concern of these researchers as well. We need to bring to a discussion the fact that many researchers treat values as if they were independent entities flying within an arm's reach only to pick them up, and they use a quantitative research tools inappropriately where more personalist approach is needed.

We offer a different picture of values from what is generally accepted here. We highlight the idea of Brožík and Vaross, that values are not only important, fundamental, positive ideals of a person because this is not how their existence might be explained. Values come from human everyday experience and thus, they cannot be separated from it. If a person reveals a higher form of certain value like love, it can only emerge from his or her experience with love, which is built from as many relationships to other people, things, creatures etc., which gives him or her the idea of this value.

The research design we offered here should be considered a mere inspiration for those who agree with us that a qualitative design to investigate values brings more 
valid results and that the composition of such a design might be easy, short and still sufficient.

\section{Acknowledgement}

Internal grant of Faculty of Education, Palacký Univerzity Olomouc: From subjective implicit theories of education to teaching knowledge. The process of constitution of a cognitive framework sciences education in the national and international context.

\section{References}

Brožík, V. (2004). Hodnotenie a hodnoty. Prešov: Vydavatelstvo Michala Vaška.

Cakirpaloglu, P. (2009). Psychologie hodnot. $2^{\text {nd }}$ revised edition. Olomouc: Vydavatelství Univerzity Palackého.

Hendl, J. (2005). Kvalitativní výzkum: základní metody a aplikace. Praha: Portál.

Průcha, J., Walterová, E., Mareš, J. (2009). Pedagogický slovník. $6^{\text {th }}$ updated and revised edition. Praha: Portál.

Rokeach, M. (1970). Beliefs, attitudes and values: A theory of organization and change. San Francisco: Jossey-Bass.

Shalom, H. S. (2015). Basic individual values: sources and consequences. In Brosch, T., In Sander, D., Clément, F., Deonna, J. A., Fehr, E., \& Vuilleumier, P. (2016). Handbook of value: Perspectives from economics, neuroscience, philosophy, psychology and sociology. DOI:10.1093/acprof:oso/ 9780198716600.001 .0001$.

Vicario, C. M. (2013). Inborn mechanisms of food preference and avoidance: the role of polymorphisms in neuromodulatory systems. Frontiers in Molecular Neuroscience, 6, 16. http://doi.org/ 10.3389/fnmol.2013.00016

\section{Contact:}

Mgr. Adéla Antlová

doc. Mgr. Štefan Chudý, Ph.D.

Ústav pedagogiky a sociálních studií

Pedagogická fakulta, Univerzita Palackého v Olomouci

Žižkovo nám. 5, 77140 Olomouc, Czech Republic

E-mail: adela.antlova@upol.cz; stefan.chudy@upol.cz 